\title{
FACILE SYNTHESIS AND In-vitro MICROBIAL EXPLORATION OF FURYL BASED 2-CYANOIMINO DIHYDROPYRIMIDINES
}

\author{
C. Vignesh and N. Ingarsal ${ }^{\bowtie}$ \\ Post Graduate and Research Department of Chemistry, Rajah Serfoji Government College, \\ Thanjavur (Affiliated to Bharathidasan University, Thiruchirappalli-24), Tamil Nadu, India. \\ ${ }^{\circledR}$ Corresponding Author: ningars@rediffmail.com
}

\begin{abstract}
Microbial evaluation and spectral assignment of newly synthesized furyl based cyanoiminopyrimidines (3a-3g) have been reported. The method involved: the reaction of 2-Acetyl-5-methylfuran with substituted benzaldehyde using basic alcoholic medium affords styryl-2-furylketones, a substituted $\alpha, \beta$-unsaturated ketones(2a-2g).Treatment ofstyryl-2-furylketones with Dicyandiamide in ethanol using sodium hydroxide leads to 2-Cyanoimino-4substituted phenyl-6-(5-methyl-2-furyl)-3,4-dihydropyrimidines. The synthesized targets were analyzed their spectral data viz. NMR, IR and Mass and assigned their structures. Screened bacterial and fungal activities of synthesized compounds especially the phenyl ring with chloro, methyl and methoxy substitution manifested the good antimicrobial potential.
\end{abstract}

Keywords: Synthesis, 1-(5-Methyl-2-furyl)ethanone, 5-Methyl-2-furyl-3-arylprop-2-en-1-one, Cyanoguanidine, Cyanoiminopyrimidine, Microbial exploration.

RASĀYAN J. Chem., Vol. 14, No.3, 2021

\section{INTRODUCTION}

Recent drug inventing scenario mainly focuses the drug molecules with efficient multifaceted therapeutic utility obtained from simple and hazards free methodology for curing diseases concerned with human beings. Reports describe heterocycles with multi-functionalization notably pyrimidines and aminopyrimidines exhibits specific biological activities, as antimalarial ${ }^{1}$, antitubercular ${ }^{2}$, cardio protective $^{3}$, antifungal ${ }^{4}$, anticancer ${ }^{5}$, antioxidant ${ }^{6}$ etc. and are present in many natural products like guanine $^{7}$, meridianins ${ }^{8}$, etc. Cyanamides, a substituted amino nitrile showed an enhanced nucleophilicity at nitrile nitrogen is responsible for observed biological activities ${ }^{9}$ especially built with heterocycles.

Alkyl / arly-substituted cyanamides / cyanimides and cyanoimines ( $N \equiv \mathrm{C}-\mathrm{NHR} / \mathrm{RR}$ 'N-C $\equiv \mathrm{N}$ and $\mathrm{N} \equiv \mathrm{C}-\mathrm{N}=$ ) are structurally related and used to built different functionalized molecules to deserve medicinally significant targets. N-cyanoimines received considerable attention in heterocyclic synthesis due to their broad spectrum of therapeutic utility such as antimycotic ${ }^{10}$, hypoglycaemic ${ }^{11,12}$ etc. and are obtained from cyanamide with ketone ${ }^{13} /$ diketone $^{14}$ or bis (trimethylsilyl) carbodiimide ${ }^{15}$ or cyanogen azide with olefin. ${ }^{16}$ Cyanoiminopyrimidines display a wide range of biological activities, for instance, act as an antagonist of $\mathrm{A}_{2 \mathrm{~B}}$ Adenosine receptor that regulates physiopathological events ${ }^{17}$, cytotoxic against breast cancer cell lines ${ }^{18}$ etc. and an alternate view on substituted furyl heteroaromatics like furyl based pyrimidines act as antimicrobial, ${ }^{19}$ antimycobacterial ${ }^{20}$ etc. Concerning the importance of cyanoimines, pyrimidines and furyl cores, this report delivers a novel synthesis of furyl based cyanoiminopyrimidines using the easily accessible method with available chemicals.

\section{EXPERIMENTAL}

Digital melting point apparatus used for melting point determination. Chemicals for experiments were procured from E-Merk and Sigma-Aldrich of higher grade and purified by appropriate process. The compounds purity checked in all stages by silica-coated aluminium plates and separated the final product by column chromatography. IR spectra were recorded with FT-IR Nicolet AVATAR-360 spectrophotometer using $\mathrm{KBr}$ pellets. The $\mathrm{NMR}-{ }^{1} \mathrm{H}$ and ${ }^{13} \mathrm{C}$ were recorded using $\mathrm{CDCl}_{3}-\mathrm{d} 6$ in a Broker 
RASĀYAN J. Chem.

Vol. 14 | No. 3 |1611-1616| July - September | 2021

(AMX-400/300 MHz) instrument and tetramethylsilane as internal standard. Agilent-GC7890A MS5975C instrument used to record the Mass spectrum.

Preparation of 1-(5-Methyl-2-furyl)-3-substituted phenylprop-2-ene-1-ones (2a-g)

An equimolar $(20 \mathrm{mM})$ ratio of 1-(5-Methyl-2-furyl) ethanone and substituted benzaldehyde in $50 \mathrm{ml}$ of ethanol was put in a $100 \mathrm{ml}$ reaction flask and kept over a water bath. About $5 \mathrm{ml}$ of $30 \%$ sodium hydroxide solution was added slowly at reflux with stirring. On cooling, the separated solid was filtered, dried and crystallized with ethanol.

\section{Synthesis of 2-Cyanoimino-4-substituted phenyl-6-(5-methyl-2-furyl)-3,4-dihydro-1H-pyrimidine (3a-g)}

A mixture of 1-(5-Methyl-2-furyl)-3-aryl-prop-2-en-1-one (10 mM),cyanoguanidine (10 $\mathrm{mM})$ and sodium hydroxide $(30 \%, 5 \mathrm{ml})$ was refluxed in ethanol $(50 \mathrm{ml})$. The TLC was utilized to detect the reaction progress and solvent was recovered to about $60 \%$ (after reaction completion, under reduced pressure). The mass poured into chilled water and crude product obtained by filtration was dried and purified by column chromatography using benzene-ethyl acetate as eluent.

\section{2-Cyanoimino-6-(5-methyl-2-furyl)-4-phenyl-3,4-dihydro-1H-pyrimidine (3a)}

M.F: $\mathrm{C}_{16} \mathrm{H}_{14} \mathrm{~N}_{4} \mathrm{O}$,Melting Point: $98{ }^{\circ} \mathrm{C}$,Yield: $90 \%$; ${ }^{1} \mathrm{H}$ NMR $(\delta, p p m): 5.96$ (furyl $\mathrm{C}_{4}-\mathrm{H}, \mathrm{d}, \mathrm{J}=2.4 \mathrm{~Hz}$ ), 6.39(furyl $\left.\mathrm{C}_{3}-\mathrm{H}, \mathrm{d}, \mathrm{J}=2.8 \mathrm{~Hz}\right), 2.22\left(\mathrm{CH}_{3}, \mathrm{~s}\right), 5.24\left(\mathrm{C}_{4} \& \mathrm{C}_{5}-\mathrm{H}, \mathrm{d}, \mathrm{J}=8.8 \mathrm{~Hz}\right), 6.46(\mathrm{NH}, \mathrm{s}), 7.17-7.42$ [(ArH $+\mathrm{NH}), \mathrm{m}] ;{ }^{13} \mathrm{C}$ NMR $(\delta, \mathrm{ppm}):(\mathrm{C} \equiv \mathrm{N}) 116.35$, (6-C) 153.49, (5-C) 96.85, (4-C) 55.86, (2-C) 155.58, 107.94-108.21 (Ar-furyl) , $13.61\left(\mathrm{CH}_{3}\right)$ and 125.02-144.10 (Ar-ph); FT-IR $\left(\mathrm{KBr}-\mathrm{cm}^{-1}\right)$ : $(\mathrm{C}=\mathrm{C}) 1513$, $(\mathrm{N}=\mathrm{C})$ 1631, $(\mathrm{N} \equiv \mathrm{C})$ 2177, $(\mathrm{NH}) 3260,3398$.

2-Cyanoimino-4-(o-chlorophenyl)-6-(5-methyl-2-furyl)-3,4-dihydro-1H-pyrimidine (3b) M.F: $\mathrm{C}_{16} \mathrm{H}_{13} \mathrm{~N}_{4} \mathrm{OCl}$, Melting Point : $126{ }^{\circ} \mathrm{C}$, Yield: 82\%; ${ }^{1} \mathrm{H}$ NMR $(\delta, p p m): 6.05$ (furyl $\mathrm{C}_{4}-\mathrm{H}, \mathrm{d}, \mathrm{J}=2.4 \mathrm{~Hz}$ ), 6.47 ( furyl $\left.\mathrm{C}_{3}-\mathrm{H}, \mathrm{d}, \mathrm{J}=3.3 \mathrm{~Hz}\right), 2.31\left(\mathrm{CH}_{3}, \mathrm{~s}\right), 5.37\left(\mathrm{C}_{4}-\mathrm{H}\right.$, distor.dd, $\left.\mathrm{J}_{1,2}=1.8 \mathrm{~Hz}, \mathrm{~J}_{1,3}=3.9 \mathrm{~Hz}\right), 5.79\left(\mathrm{C}_{5}-\mathrm{H}\right.$, dd, $\left.\mathrm{J}_{1,2}=2.1 \mathrm{~Hz}, \mathrm{~J}_{1,3}=4.2 \mathrm{~Hz}\right), 6.28(\mathrm{NH}, \mathrm{s}), 7.29-7.44[(\mathrm{ArH}+\mathrm{NH}), \mathrm{m}] ;{ }^{13} \mathrm{C} \mathrm{NMR}(\delta, \mathrm{ppm}):(\mathrm{C} \equiv \mathrm{N}) 117.30$, $(6-$ C) $153.08,(5-\mathrm{C}) 94.45$, (4-C) 52.09, (2-C) 156.22, 107.67-108.77 (Ar-furyl), $13.50\left(\mathrm{CH}_{3}\right)$ and 126.08144.45 (Ar-ph); FT-IR $\left(\mathrm{KBr}-\mathrm{cm}^{-1}\right)$ : $(\mathrm{C}=\mathrm{C}) 1525,(\mathrm{~N}=\mathrm{C}) 1645,(\mathrm{~N} \equiv \mathrm{C}) 2182,(\mathrm{NH}) 3239$.

2-Cyanoimino-4-(p-chlorophenyl)-6-(5-methyl-2-furyl)-3,4-dihydro-1H-pyrimidine (3c)

M.F: $\mathrm{C}_{16} \mathrm{H}_{13} \mathrm{~N}_{4} \mathrm{OCl}$, Melting Point:114 ${ }^{\circ}$ C, Yield: 85\%; ${ }^{1} \mathrm{H}$ NMR $(\delta, p p m)$ : 6.06 (furyl $\mathrm{C}_{4^{-}}$ $\mathrm{H}, \mathrm{d}, \mathrm{J}=3.3 \mathrm{~Hz}), 6.46\left(\mathrm{C}_{3}-\mathrm{H}, \mathrm{d}, \mathrm{J}=3.3 \mathrm{~Hz}\right), 2.32\left(\mathrm{CH}_{3}, \mathrm{~s}\right), 5.37\left(\mathrm{C}_{4}-\mathrm{H}\right.$, distor.dd, $\left.\mathrm{J}_{1,2}=2.1 \mathrm{~Hz}, \mathrm{~J}_{1,3}=4.2 \mathrm{~Hz}\right), 5.80\left(\mathrm{C}_{5}-\mathrm{H}\right.$, $\left.\mathrm{dd}, \mathrm{J}_{1,2}=2.1 \mathrm{~Hz}, \mathrm{~J}_{1,3}=4.2 \mathrm{~Hz}\right), 6.22(\mathrm{NH}, \mathrm{s}), 7.29-7.44[(\mathrm{ArH}+\mathrm{NH}), \mathrm{m}] ;{ }^{13} \mathrm{C}$ NMR $(\delta, \mathrm{ppm}):(\mathrm{C} \equiv \mathrm{N}) 116.82$, (6-C) 143.88, (5-C) 93.95, (4-C) 51.46, (2-C) 152.55, 107-108 (Ar-furyl), $12.97\left(\mathrm{CH}_{3}\right)$ and 125.41-139.36

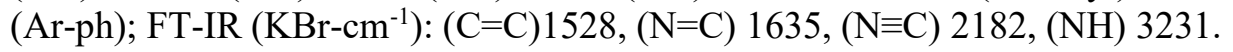

2-Cyanoimino-4-(m-chlorophenyl)-6-(5-methyl-2-furyl)-3,4-dihydro-1H-pyrimidine (3d) M.F: $\mathrm{C}_{16} \mathrm{H}_{13} \mathrm{~N}_{4} \mathrm{OCl}$, Melting Point : $94{ }^{\circ} \mathrm{C}$, Yield: $75 \%$; ${ }^{1} \mathrm{H}$ NMR $(\delta, \mathrm{ppm}): 5.95$ ( furyl $\mathrm{C}_{4}-\mathrm{H}, \mathrm{d}$ ), 6.40 (furyl $\left.\mathrm{C}_{3}-\mathrm{H}, \mathrm{d}, \mathrm{J}=3.2 \mathrm{~Hz}\right), 2.10\left(\mathrm{CH}_{3}, \mathrm{~s}\right), 5.19\left(\mathrm{C}_{4}-\mathrm{H}, \mathrm{d}\right), 5.23\left(\mathrm{C}_{5}-\mathrm{H}, \mathrm{d}\right), 6.47(\mathrm{NH}, \mathrm{s}), 7.14-7.29[(\mathrm{ArH}+\mathrm{NH}), \mathrm{m}]$; ${ }^{13} \mathrm{C}$ NMR $(\delta, p p m):(\mathrm{C} \equiv \mathrm{N}) 117,(6-\mathrm{C}) 153.71,(5-\mathrm{C})$ 95.93, (4-C) 55.38, (2-C) 155,45, 108.02-108.43 (Arfuryl $)$ 13.66 $\left(\mathrm{CH}_{3}\right)$, and 125.04-143.84 (Ar-ph); FT-IR $\left(\mathrm{KBr}_{-} \mathrm{cm}^{-1}\right):(\mathrm{C}=\mathrm{C}) 1512,(\mathrm{~N}=\mathrm{C}) 1630,(\mathrm{~N} \equiv \mathrm{C})$ 2181, (NH) 3268.

2-Cyanoimino-6-(5-methyl-2-furyl)-4-( $p$-methylphenyl)-3,4-dihydro-1H-pyrimidine (3e) M.F: $\mathrm{C}_{17} \mathrm{H}_{16} \mathrm{~N}_{4} \mathrm{O}$, Melting Point: $142{ }^{\circ} \mathrm{C}$, Yield: $78 \%$; ${ }^{1} \mathrm{H}$ NMR $(\delta, p p m)$ : 6.01 (furyl $\mathrm{C}_{4}-\mathrm{H}, \mathrm{d}, \mathrm{J}=2.7 \mathrm{~Hz}$ ), 6.70 (furyl $\mathrm{C}_{3}-\mathrm{H}, \mathrm{d}, \mathrm{J}=3.3 \mathrm{~Hz}$ ), 2.27( $\left.\mathrm{CH}_{3}, \mathrm{~s}\right), 5.24\left(\right.$ br.s, $\left.\mathrm{C}_{4}-\mathrm{H}\right), 5.29\left(\right.$ br.s, $\left.\mathrm{C}_{5}-\mathrm{H}\right), 6.40(\mathrm{NH}, \mathrm{s}), 7.08-$ 7.44[(ArH+NH),m] and 2.35( $\left.\mathrm{CH}_{3}, \mathrm{~s}\right) ;{ }^{13} \mathrm{C}$ NMR $(\delta, \mathrm{ppm}):(\mathrm{C} \equiv \mathrm{N}) 116.52$, (6-C) 151.65, (5-C) 95.74, (4-C) 53.57, (2-C) 154.67, 106.56-107.68 (Ar-furyl) ,12.44 ( $\left.\mathrm{CH}_{3}\right), 124.43-143.71$ (Ar-ph) and $\left(\mathrm{CH}_{3}\right)$ 19.99; FTIR $\left(\mathrm{KBr}-\mathrm{cm}^{-1}\right)$ : $(\mathrm{C}=\mathrm{C}) 1527,(\mathrm{~N}=\mathrm{C}) 1640,(\mathrm{~N} \equiv \mathrm{C}) 2185,(\mathrm{NH}) 3234$.

2-Cyanoimino-4-(p-methoxyphenyl)-6-(5-methyl-2-furyl)-3,4-dihydro-1H-pyrimidine (3f) M.F: $\mathrm{C}_{17} \mathrm{H}_{16} \mathrm{~N}_{4} \mathrm{O}_{2}$, Melting Point : 82 ${ }^{\circ} \mathrm{C}$, Yield: $76 \%$; ${ }^{1} \mathrm{H}$ NMR $(\delta, p p m): 6.04$ (furyl $\mathrm{C}_{4}-\mathrm{H}, \mathrm{d}, \mathrm{J}=2.7 \mathrm{~Hz}$ ), 6.44 ( furyl $\left.\mathrm{C}_{3}-\mathrm{H}, \mathrm{d}, \mathrm{J}=3.3 \mathrm{~Hz}\right), 2.30\left(\mathrm{CH}_{3}, \mathrm{~s}\right), 5.27\left(\mathrm{C}_{4} \& \mathrm{C}_{5}-\mathrm{H}, \mathrm{s}\right), 6.38(\mathrm{NH}, \mathrm{s}), 6.89-7.36[(\mathrm{ArH}+\mathrm{NH}), \mathrm{m}]$, 
RASĀYAN J. Chem.

Vol. 14 | No. 3 |1611-1616| July - September | 2021

3.81 $\left(\mathrm{OCH}_{3}, \mathrm{~s}\right) ;{ }^{13} \mathrm{C} \mathrm{NMR}(\delta, \mathrm{ppm}):(\mathrm{C} \equiv \mathrm{N}) 116.95$, (6-C) 153.37, (5-C) 97.11, (4-C) 55.19, (2-C) 155.43, 107.87-108.10 (Ar-furyl),13.55 $\left(\mathrm{CH}_{3}\right), 124.31-144.12(\mathrm{Ar}-\mathrm{ph})$ and $\left(\mathrm{OCH}_{3}\right)$ 55.34; FT-IR $\left(\mathrm{KBr}-\mathrm{cm}^{-1}\right)$ : $(\mathrm{C}=\mathrm{C}) 1587,(\mathrm{~N}=\mathrm{C}) 1637,(\mathrm{~N} \equiv \mathrm{C}) 2174,(\mathrm{NH}) 3237$.

\section{2-Cyanoimino-4-(p-flurophenyl)-6-(5-methyl-2-furyl)-3,4-dihydro-1H-pyrimidine (3g)}

M.F: $\mathrm{C}_{16} \mathrm{H}_{13} \mathrm{~N}_{4} \mathrm{OF}$, Melting Point: $122{ }^{\circ} \mathrm{C}$, Yield: $80 \% ;{ }^{1} \mathrm{H}$ NMR $(\delta, p p m): 6.05$ (furyl $\mathrm{C}_{4}-\mathrm{H}, \mathrm{d}, \mathrm{J}=2.4 \mathrm{~Hz}$ ), 6.46 (furyl $\left.\mathrm{C}_{3}-\mathrm{H}, \mathrm{d}, \mathrm{J}=3.3 \mathrm{~Hz}\right), 2.31\left(\mathrm{C}_{5}-\mathrm{CH}_{3}, \mathrm{~s}\right), 5.27\left(\mathrm{C}_{4}-\mathrm{H}\right.$,distor.br.d), 5.33( $\mathrm{C}_{5}-\mathrm{H}$,distor.d), 6.49(NH,s), 7.05-7.36[(ArH+NH), m] ; ${ }^{13} \mathrm{C}$ NMR $(\delta, p p m):(\mathrm{C} \equiv \mathrm{N}) 117.09$, (6-C) 153.58, (5-C) 96.61, (4-C) 55.06, (2C) $155.48,107.97-108.42$ (Ar-furyl), $13.61\left(\mathrm{CH}_{3}\right)$ and 124.93-144.19(Ar-ph); FT-IR $\left(\mathrm{KBr}-\mathrm{cm}^{-1}\right)$ : $(\mathrm{C}=\mathrm{C}) 1526,(\mathrm{~N}=\mathrm{C})$ 1637, $(\mathrm{N} \equiv \mathrm{C})$ 2183, $(\mathrm{NH}) 3235$.

\section{RESULTS AND DISCUSSION}

Based on the significant impact of cyanamides and cyanoimines on therapeutic utility, reports suggested the different synthesis methods with structural modifications that affect the characteristics of the molecules such as steric,electronic and lipophilic factors in turn to alter the pharmacological profiles. Likewise, structurally diversified cyanoiminopyrimidines derived from different routes such as Biosteric replacement of imino/ $\mathrm{C}=\mathrm{O}$ group in pyrimidone / iminopyrimidin ${ }^{17}$, thereaction of cyanoguanidine with acrylic acid ${ }^{21}$ and MCR of aldehydes and 1,3-diketones ${ }^{22,23}$ with cyanamide displays a broad spectrum of biological activities.

Synthetic routes have been analyzed and this report is based on the reaction of cyanoguanidine with unsaturated ketones in a simple route. The synthetic strategy present inScheme-1: The 1-(5-Methyl-2furyl)ethanone on Claisen-Schmit condensation with substituted benzaldehyde using sodium hydroxide gives the chalcone, 1-(5-methyl-2-furyl)-3-aryl-prop-2-en-1-one (2a-g) and the target scaffold 2cyanoimino-4-substituted phenyl-6-(5-methyl-2-furyl)-3,4-dihydro-1H-pyrimidines (3a-g) were obtained in basic ethanolic medium by treating $(2 \mathrm{a}-\mathrm{g})$ with cyanoguanidine.

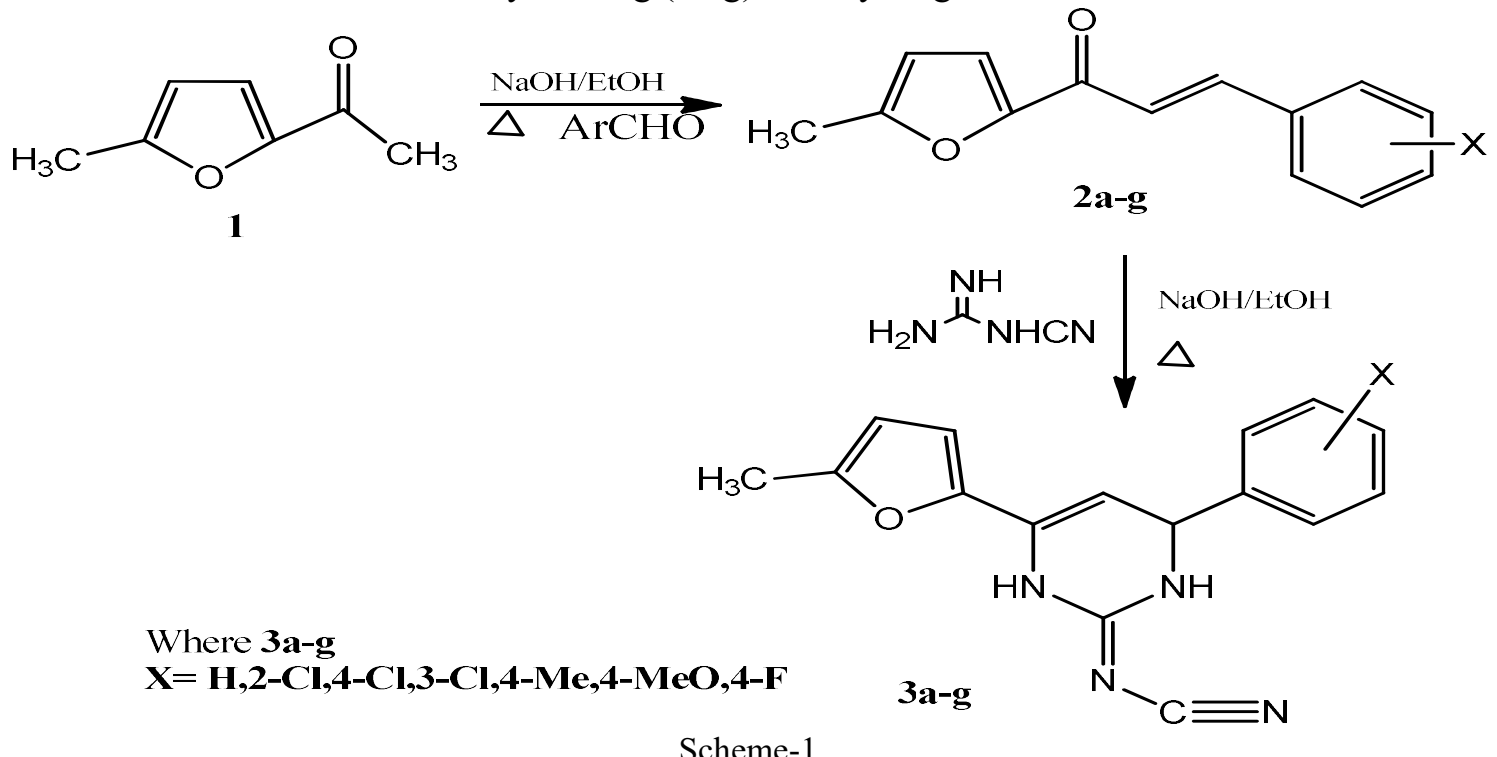

Scheme-1

The formation of assigned products is believed to proceed with the addition of cyanoguanidine either by 1,2- or1,4 manner or both to the 2-furylstyryl ketones (chalcones) andsubsequently the cyclization of resulting intermediates similar to 2-aminopyrimidine mechanism ${ }^{24}$ (Scheme-2).

The synthesized compounds (3a-g) structures are assigned based on IR, NMR, and Mass spectroscopy. The appearance of intense nitrile $(\mathrm{C} \equiv \mathrm{N})$ stretching vibrational band at around $2200 \mathrm{~cm}^{-1}$ and $-\mathrm{NH}$ stretching band at around $3250 \mathrm{~cm}^{-1}$ suggest their presence in structure. Other absorption bands $\approx 1640 \mathrm{~cm}$ ${ }^{1}(\mathrm{C}=\mathrm{N}), \mathrm{C}=\mathrm{C} \approx 1520 \mathrm{~cm}^{-1}$ and furanyl $\mathrm{C}-\mathrm{O}-\mathrm{C} \approx 1200 \mathrm{~cm}^{-1}$ reflect the additional information in the structure.

The proton NMR spectrum showed two aromatic furanyl protons in the shielded region (6.0-6.5 ppm) regarding phenyl protons. The doublet at around $6.0 \mathrm{ppm}\left(\mathrm{J}_{1,2} \approx 2.5 \mathrm{~Hz}\right)$ is responsible for furanyl proton 
adjacent to methyl group and another doublet $(\approx 6.46 \mathrm{ppm})\left(\mathrm{J}_{1,2} \approx 3 \mathrm{~Hz}\right)$ is for one more furanyl proton. The discrete $\mathrm{D}_{2} \mathrm{O}$ exchangeable broad singlet in the region of 6.2 to $6.5 \mathrm{ppm}$ is for one $\mathrm{NH}$ proton. The compounds with 4-methoxy and 4-methyl phenyl substitution give the other NH protons at $7.30 \mathrm{ppm}$ as separate signals and the remaining cyanoiminopyrimidines appear as merged signals with aromatic phenyl protons at (7.0-7.4ppm).

Pyrimidine ring protons (H-4 and H-5) showed the signals at around 5.2-5.8ppm. The C-5 proton at in ethylenic double bond in conjugation with furyl ring observes in the deshielded position from C-4 proton. The multiplicity pattern of these protons varies accordingly to the substituent at the phenyl ring. The compounds with electronegative chlorine, fluorine and without substitution showed doublets/ doublet of doublets for these protons. More specifically, in o- and p-chloro substitution, the H-4 proton resonates at $5.37 \mathrm{ppm}$ as a distorted doublet of doublet $\left(\mathrm{J}_{1,2} \approx 2.12 \mathrm{~Hz}, \mathrm{~J}_{1,3} \approx 4.2 \mathrm{~Hz}\right)$ and $\mathrm{H}-5$ proton gives a clear doublet of doublet at 5.80ppm $\left(\mathrm{J}_{1,2}=2.1 \mathrm{~Hz}\right.$ and $\left.\mathrm{J}_{1,3}=4.2 \mathrm{~Hz}\right)$ respectively.

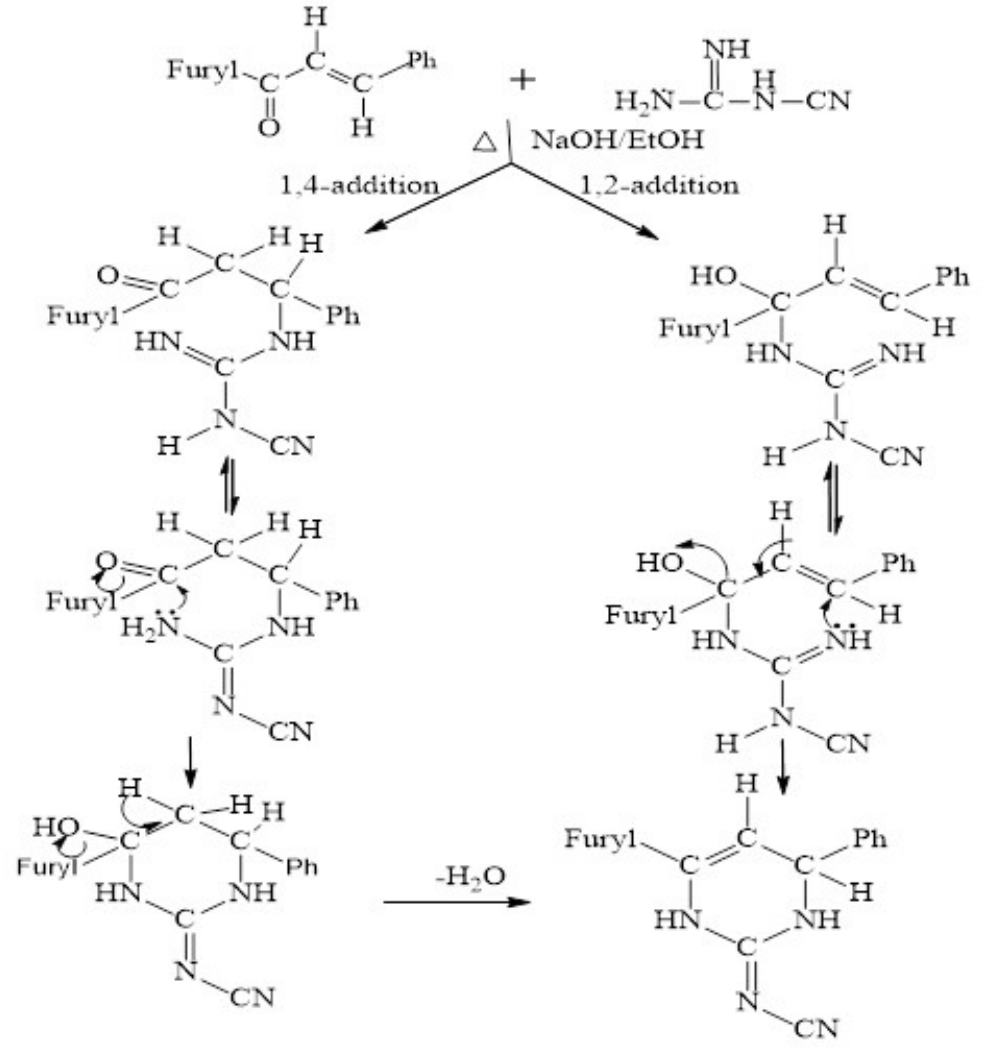

Scheme-2: Mechanism for Cyanoiminopyrimidine Formation

The compounds with para fluoro and meta chloro give distorted doublet or doublet for protons at C-4 and C-5. The simple phenyl substituted pyramidine, both protons $\mathrm{H}-4$ and $\mathrm{H}-5$ resonate at $5.24 \mathrm{ppm}$ as a doublet. The electron-rich methyl and methoxy substituted pyrimidine ring protons observed in the same chemical shift region as two different singlets. The observed multiplicity pattern of these synthesized pyrimidines (3a-g) reveals the electronic facts that disturbed the multiplicity pattern, especially the broadening and distorted signals.

The observed ${ }^{13} \mathrm{C}$ NMR chemical shift values support the structural assignment based on ${ }^{1} \mathrm{H}$ NMR and IR data. The carbon-13 signals of $3 \mathrm{a}-\mathrm{g}$ were observed at $\approx 116$ for nitrile carbon $(\mathrm{C} \equiv \mathrm{N}), \approx 55 \mathrm{ppm}(4-\mathrm{C})$, $\approx 96 \mathrm{ppm}(5-\mathrm{C}), \approx 153 \mathrm{ppm}(6-\mathrm{C})$ and $\approx 155$ (Quaternary carbon at C-2), respectively. The mass spectrum of 2-chloro substituted cyanoiminopyrimidine shows $\mathrm{M}^{+}$peak at $\mathrm{m} / \mathrm{z}=312$. Evidenced from obtained spectral data 's, the synthesized cyanoiminopyrimidines suggest the three different tautomeric structures viz. A, B and C (Fig.-1). Considered the earlier findings ${ }^{23,25}$ based on Quantum mechanical calculations, the more stable tautomer is assigned as structure-B. 
RASĀYAN J. Chem.

Vol. 14 | No. 3 |1611-1616| July - September | 2021<smiles>[X]c1cccc(C2C=C(c3ccc(C)o3)N=C(NC#N)N2)c1</smiles>

A



$\mathbf{B}$<smiles>[X]c1ccccc1C1C=C(c2ccc(C)o2)NC(NC#N)=N1</smiles>

C

\section{Antimicrobial Screening}

Fig.-1

The antimicrobial such as antibacterial and antifungal activities was tested for synthesized compounds 3ag against selected microorganisms and compared with the standard drugs selected for bacterial and fungal are Nitrofurantoin and Amphotericin-B, respectively (Table-1).

Table-1: Antimicrobial activity

Standards: Nitrofurantoin (bacteria) and Amphotericin B (fungi)

\begin{tabular}{|c|c|c|c|c|c|c|c|c|c|c|}
\hline \multirow[t]{2}{*}{ S.No. } & Microorganism & \multicolumn{9}{|c|}{ Diameter of Inhibition Zone (mm) } \\
\hline & Bacteria & Standard* & Control & $3 a$ & $3 b$ & $3 \mathrm{c}$ & $3 \mathrm{~d}$ & $3 \mathrm{e}$ & $3 \mathrm{f}$ & $3 g$ \\
\hline 1 & Bacillus subtilis & 23 & - & 15 & 16 & 14 & 15 & 15 & 16 & 15 \\
\hline 2 & Escherichia coli & 24 & - & 19 & 20 & 17 & 22 & 18 & 17 & 16 \\
\hline 3 & Staphylococcus aureus & 22 & - & 16 & 17 & 17 & 16 & 15 & 16 & 16 \\
\hline 4 & Vibro cholerae & 19 & - & 7 & 9 & 9 & 8 & 13 & 12 & 9 \\
\hline \multicolumn{11}{|c|}{ Fungi } \\
\hline 5 & Aspergillus flavus & 18 & - & 9 & 10 & 9 & 10 & 12 & 11 & 13 \\
\hline 6 & Penicilliumchrysogenu & 19 & - & 11 & 12 & 14 & 9 & 15 & 14 & 14 \\
\hline
\end{tabular}

All the tested pyrimidines showed moderate activity against microbes compared to standards, especially the chloro substituted $3 \mathrm{~b}$ and $3 \mathrm{c}$ showed nearly more than $70 \%$ activity from standard. The compounds were more active against Escherichia coli and the order is Escherichia coli $>$ Staphylococcus aureus $>$ Bacillus subtilis $>$ vibrio cholerae. The compounds with 4-Me and 4-Meo (3e and 3f) showed nearly $65 \%$ active against vibrio chlorae and other compounds are less active. Among chloro substituted, orthochloro substituted pyrimidine exhibits a good antibacterial profile and is $2 \mathrm{Cl}>3 \mathrm{Cl}>4 \mathrm{Cl}$. The fungal activity analysis reveals that the compounds with 4-F, 4-Me and 4-Meo showed more activity (more than $65 \%$ ) than other tested compounds. All the compounds are moderately active against tested fungi and more active against penicillium chrysogenum.

\section{CONCLUSION}

The microbial active 2-Cyanoimino-4-substituted phenyl-6-(5-methyl-2-furyl)-3,4-dihydro-1Hpyrimidines synthesized by the reaction of cyanoguanidine with 1-(5-Methyl-2-furyl)-3-aryl-prop-2-ene1 -ones in the presence of sodium hydroxide. The compounds were characterized by NMR, Mass and IR spectral studies. The synthesized furyl based pyrimidines tested their in vitro antimicrobial activity with reference to Nitrofurantoin (bacteria) and Amphotericin B (fungal) and proved to control the tested microbial growth.

\section{ACKNOWLEDGEMENT}

Authors thankful to Annamalai University, Annamalai Nagar, Sastra University, Thanjavur and TUV.SUD.South Asia Pvt. Ltd, Thirupur, Tamil Nadu, for providing the spectral facilities.

\section{REFERENCES}

1. A. J. Lin, L. Q. Li, D. L. Klayman, C. F. George and J. L. Flippen-Anderson, Journal of Medicinal Chemistry,33(9), 2610(1990), https://doi.org/10.1021/jm00171a041

2. A. B. Siddiqui, A. R. Trivedi, V. B. Kataria and V. H. Shah, Bioorganic \& Medicinal Chemistry Letters, 24(6), 1493(2014), https://doi.org/10.1016/j.bmcl.2014.02.012 
RASĀYAN J. Chem.

Vol. 14 | No. 3 |1611-1616| July - September | 2021

3. M. Baumgarth, N. Beier and R. Gericke, Journal of Medicinal Chemistry,40(13), 2017 (1997), https://doi.org/10.1021/jm960768n

4. M. Someswara Rao, T. Bhaskara Rao and C. P. Koteswara, Rasayan Journal of Chemistry, 13(3),1513(2020), https://doi.org/10.31788/RJC.2020.1335799

5. N. M. Ahmed, M. Youns, M. K. Soltan and A. M. Said, Journal of Enzyme Inhibition and Medicinal Chemistry, 34(1), 1110 (2019), https://doi.org/10.1080/14756366.2019.1612889

6. D. M. Sirsat, P. S. Bhale, H. V. Chavan, S. M. Karap and M. T. Bachute, Rasayan Journal of Chemistry, 13(3), 1589(2020), https://doi.org/10.31788/RJC.2020.1335768

7. I. M. Lagoja, Chemistry \& Biodiversity,2(1), 1(2005), https://doi.org/10.1002/cbdv.200490173

8. A. H. Sandtorv, Studies in Natural Products Chemistry, Elsevier, Publisher: John Fedor, 53, 143 (2017).

9. J. P. Falgueyret, R. M. Oballa, O. Okamoto, G. Wesolowski, Y. Aubin, R. M. Rydzewski, P. Praist, D. Reindeau, S. B. Ridab and M. D. Percival, Journal of Medicinal Chemistry,44(1), 94(2001), https://doi.org/10.1021/jm0003440

10. A. Kreutzberger and M. Sellheim, Journal of Heterocyclic Chemistry, 22(3), 721(1985), https://doi.org/10.1002/jhet.5570220321

11. F. Ishikawa, A. Kosasayama, and T. Konuo, Chemical and Pharmaceutical Bulletin,26(12), 3658(1978), https://doi.org/10.1248/cpb.26.3658

12. A. Kosasayama, T. Konno, K. Higashi and F. Ishikawa, Chemical and Pharmaceutical Bulletin, 27(4), 841(1979), https://doi.org/10.1248/cpb.27.841

13. D. D. Nekrasov, Russian Journal of Organic Chemistry, 40(10), 1387(2004), https://doi.org/10.1007/s11178-005-0030-4

14. A. Miller, Journal of Organic Chemistry,49(21), 4072(1984), https://doi.org/10.1021/jo00195a043

15. A. Aumuller and S. Hunig, Angewandte Chemie, 96(6), 437(1984), https://doi.org/10.1002/ange.19840960620

16. F. D. Marsh and M. E. Hermes, Journal of the American Chemical Society, 86(20), 4506(1964), https://doi.org/10.1021/ja01074a071

17. C. Carbajales, J. Azuaje, A. Oliveira, M. I. Loza, J. Brea, M. I. Cadavid, C. F. Masaguer, X. GarciaMera, H. Gutierrez-de-Teran and E. Sotelo, Journal of Medicinal Chemistry, 60(8), 3372(2017), https://doi.org/10.1021/acs.jmedchem.7b00138

18. A. E. E. Amr, E. A. Elsayed, M. A. Al-Omar, H. O. Badr-Eldin, E. S. Nossier and M. M. Abdallah, Molecules, 24(3),416 (2019), https://doi.org/10.3390/molecules24030416

19. W. A. Ei-Sayed, I. F. Nassar and A. A. H. Abdel-Rahman, Monatshefte Fur Chemie-Chemical Monthly, 140(4), 365(2009), https://doi.org/10.1007/s00706-008-0033-2

20. M. Ashraf Ali, E. Manogaran, J. Govindasamy, V. Sellappan and S. Pandian, Journal of Enzyme Inhibition and Medicinal Chemistry, 26(1), 149(2011), https://doi.org/10.3109/14756366.2010.482046

21. P. Aleksandrowicz, M. Bukowska, M. Maciejewski, and J. Prejzner, Canadian Journal of Chemistry, 57(19), 2593(1979), https://doi.org/10.1139/v79-419

22. A. H. Moustafa, A.S. Shestakov and Kh. S. Shikhaliev, Chemistry of Heterocyclic Compounds, 48(4), 613(2012), https://doi.org/10.1007/s10593-012-1034-y

23. R. Hulme, O. D. P. Zamora, E. J. Mota, M. A. Pasten, R. Contreras-Rojas, R. Miranda, I. ValenciaHernandez, J. Correa-Basurto, J. Trujillo-Ferrara and F. Delgado, Tetrahedron, 64(15), 3372(2008), https://doi.org/10.1016/j.tet.2008.01.087

24. N. R. El-Rayyes, Journal of Heterocyclic Chemistry, 19(2), 415(1982), https://doi.org/10.1002/jhet.5570190240

25. S. Sivagami and N. Ingarsal, Oriental Journal of Chemistry, 34(2), 777(2018), https://doi.org/10.13005/ojc/340222

[RJC-6364/2021] 